\title{
Trigeneration Systems with Fuel Cells
}

\author{
J.I. San Martín ${ }^{1}$, I. Zamora ${ }^{2}$, J.J. San Martín ${ }^{1}$, V. Aperribay ${ }^{1}$, P. Eguía ${ }^{2}$ \\ Department of Electrical Engineering - University of the Basque Country \\ ${ }^{1}$ Escuela Universitaria de Ingeniería Técnica Industrial de Eibar \\ Avda. Otaola, 29, 20600 Eibar (Spain) - e_mail: iepsadij@sb.ehu.es \\ ${ }^{2}$ Escuela Técnica Superior de Ingeniería de Bilbao \\ Alda. Urquijo s/n, 48013 Bilbao (Spain) - e_mail: inmaculada.zamora@ehu.es
}

\begin{abstract}
Trigeneration systems include those processes of production and simultaneous use of electricity, heat and cold, from a single fuel source. The simultaneous use of energy allows obtaining high levels of overall energy efficiency, lower emissions, security of supply, as well as lower losses and investments in networks.

The context of implementation of trigeneration ranges from low voltage distributed generation to the electric microgrid prototypes currently under research. In this last environment, the work is mainly focused in the following power generation technologies: Fuel Cells, Microturbines, Stirling Engines, Small Wind Turbines, and Photovoltaic plants.

This paper focuses on those research proposals that are currently being developed using fuel cells as base technology for trigeneration. The paper presents the different subsystems that are part of these power generation systems, as well as their most important characteristics and applications.
\end{abstract}

Key words: Microgrids Trigeneration, PEMFC, AFC, PAFC, MCFC, SOFC.

\section{Introduction}

Within the context of distributed generation, microgrids rely on emerging technologies, such as fuel cells, gas microturbines, Stirling engines, as well as technologies that make use of local renewable resources. On the other hand, a growing deployment of a variety of technologies that allow the effective use of waste heat for power generation is being noticed. This involves increasing the overall efficiency of the systems and a reduction in the costs of implementation [1].

Table 1 highlights the most relevant properties of the emerging power generation technologies. These are the technologies being considered in the implementation of microgrids [2].
TABLE 1. -Characteristics of emergent technologies in CCHP systems

\begin{tabular}{|c|c|c|c|}
\hline 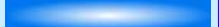 & FUEL CELLS & STIRLING ENGINES & MICROTURBINES \\
\hline CAPACITY RANGE & $5 \mathrm{~kW}-2 \mathrm{MW}$ & $1 \mathrm{~kW}-1,5 \mathrm{MW}$ & $15-300 \mathrm{~kW}$ \\
\hline FUEL USED & Hydrogenand duels cont hydrocarbons & Any (gas, alconol, butane, biogas) & Gas propane, distllate oils, bilogas \\
\hline ELECTRICAL EFFICIENCY $(\%)$ & $37-60$ & $\sim 40$ & $15-30$ \\
\hline OVERALL EFFICIENCY (\%) & $85-90$ & $65-85$ & $60-85$ \\
\hline POWER TO HEAT RATIO & $0,8-1,1$ & $1,2-1,7$ & $1,2-1,7$ \\
\hline OUTPUT HEAT TEMP.('C) & $260-370$ & $60-200$ & $200-350$ \\
\hline NOISE & Quiet & Fair & Fair \\
\hline $\mathrm{CO}_{2}$ EMISSIONS (kg/MWh) & $430-490$ & 672 & 720 \\
\hline NOX EMISSIONS (kgIMWh) & $0,005-0,010$ & 0,23 & 0,1 \\
\hline AVALABILITY (\%) & $90-95$ & N/A & 98 \\
\hline PART LOAD PERFORMANCE & Good & Good & Fair \\
\hline LIFE CYCLE (year) & $10-20$ & 10 & 10 \\
\hline AVERAGECOST INVESTMENT $(5 \mathrm{kM}$ & $2500-3500$ & $1300-2000$ & $900-1500$ \\
\hline OPERATING \&MAINTEN. COST $(5 \mathrm{KMM}$ & $0,007-0,050$ & N/A & $0,01-0,02$ \\
\hline
\end{tabular}

In this field, cogeneration is the most outstanding technique for simultaneous production of electricity and heat [1]. If, in addition, a process requires of cooling levels below the ambient temperature (cold air, cold water or ice), and the cooling is produced from the same energy source, then, the generation process is called trigeneration. This cooling can be done through processes of absorption or adsorption.

Besides, trigeneration presents several advantages, being the most relevant:

- An increase in the equivalent electrical efficiency of the cogeneration plant, due to a better use of waste heat.

- A smooth operation of the plant over the year, as an increase in the demand for cooling often coincides with a reduction in the demand for heating.

- An improvement of the environmental conditions, avoiding the use of CFSs and HCFCs by using natural refrigerants.

Figure 1 shows the process diagram of a trigeneration system used for a high electrical efficiency energy system.

In this context, one of the technologies that has the best performance for being integrated into a trigeneration system is the fuel cell. Systems based on this technology 
turn, on a continuous and direct way, the energy of a chemical reaction into electrical energy, heat and water. Its modular design, low noise and emission levels, flexibility of operation and high efficiency relatively independent of the load, means that these devices are very versatile. Its main practical applications range from bulk production of electricity and heat to its use in sectors such as aerospace, maritime or surface transport and portable devices.

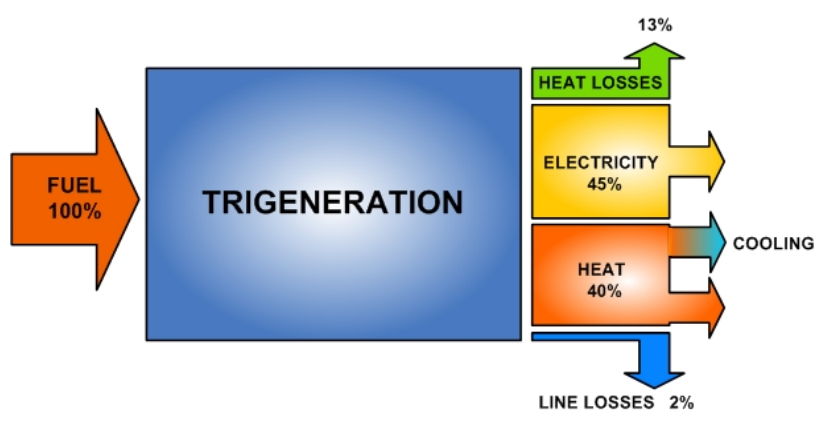

Fig 1. Schematic diagram of Trigeneration process

\section{Fuel cell technologies}

Fuel cells are classified, mainly, based on two aspects: the kind of electrolyte used and the operating temperature. With regard to this last point, we will highlight the MCFC and SOFC technology, as types of high temperature $\left(65^{\circ} \mathrm{C}\right.$ to $\left.1050^{\circ} \mathrm{C}\right)$ and PEMFC, DMFC, AFC and Membrane PAFC, as types of low temperature $\left(60^{\circ} \mathrm{C}\right.$ to $\left.250^{\circ} \mathrm{C}\right)$.

As an example, figure 2 shows a typical PEM fuel cell (low temperature), in which the reactants fed to the anode and cathode. The electrolyte separates the electrodes and allows the conduction of positive charges. The electric circuit is completed externally through a load. As a byproduct, these devices generate thermal energy. The quality of this thermal energy depends on type of fuel cell.

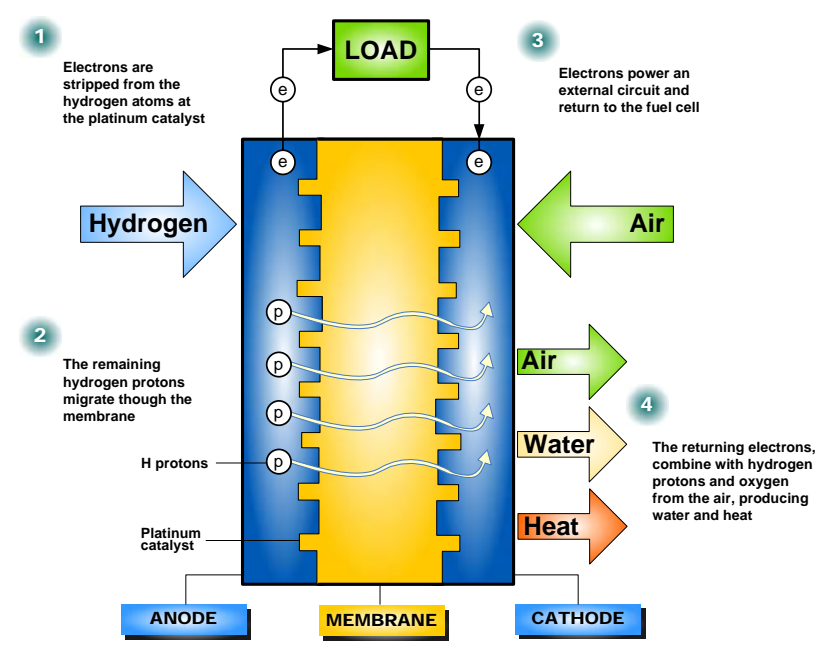

Fig 2. PEMFC operation
Fuel cells develop electrochemical exothermic reactions, so the combined use of electricity and heat gives them a high overall efficiency, around 85\% [3]. This thermal energy can be used for many purposes: within the fuel cell system, transferred outside to meet the demand of heating or cooling processes or released to the surrounding area without any application. In order to optimize the efficiency of these devices, research is being developed for the use of the thermal energy in water and air conditioning in homes, services and industrial facilities.

With the aim of releasing the heat produced by the electrochemical reaction, each certain number of cells is separated by a device, called refrigerator plate. The objective of these refrigerator plates is carried out exchanging heat to the coolant medium which is normally water. In this sense, there is a wide potential for the integration of cooling by absorption, activated by hot water or directly by the exhaust gases. An appropriate strategy consists on using the absorption equipment to accumulate cold when there is not enough demand of heat.

Low temperature fuel cells systems are cooled by air or by a liquid flowing through them. In addition, using a coolant, typically deionised water, it is easier to transfer thermal energy in a cogeneration process, either for space heating or for hot water.

In high temperature fuel cell systems, as the MCFC and SOFC technology, thermal energy is available with sufficient temperature to drive the external or internal fuel reformer. The heat from the exhaust gases can be used to preheat the incoming air. Once the heat needs of fuel cell are satisfied, thermal energy can be used to provide steam or hot water for cogeneration in a heat recovery boiler [4]. Also, in these high temperature fuel cells, since the quality of the thermal energy of the exhaust gases is high, additional production of electricity can be obtained by means of gas microturbines, forming a hybrid model.

In Table 2, the technical and economic characteristics of different fuel cell technologies are shown, in relation to power generation [5].

TABLE 2. - Technical and economic characteristics of energy station power technologies

\begin{tabular}{|c|c|c|c|c|c|c|}
\hline \multirow[b]{2}{*}{ TECH.TYPE } & \multicolumn{3}{|c|}{$\begin{array}{l}\text { LOWMMEDIUM TEMPERATURE } \\
\text { FUEL CELLL DESGN }\end{array}$} & \multicolumn{2}{|c|}{$\begin{array}{l}\text { HIGH TEMPERATURE } \\
\text { FUEL CELL DESIGN }\end{array}$} & \multirow{2}{*}{$\begin{array}{c}\begin{array}{c}\text { HYDROGEN } \\
\text { ENGINEGENSET }\end{array} \\
\text { ICEGenerator }\end{array}$} \\
\hline & PEMFC & AFC & \begin{tabular}{|l|} 
PAFC \\
\end{tabular} & MCFC & SOFC & \\
\hline $\begin{array}{l}\text { Typical } \\
\text { electrical } \\
\text { efficiency }\end{array}$ & $\begin{array}{c}30-50 \% \\
\text { NGG) } \\
40-60 \%\left(\mathrm{H}_{2}\right)\end{array}$ & $\begin{array}{c}30-50 \% \\
-\mathrm{NG}) \\
50-60 \%\left(\mathrm{H}_{2}\right)\end{array}$ & $37-42 \%$ & $50-60 \%$ & $45-60 \%$ & $25-35 \%$ \\
\hline Operating temperature & $-80^{\circ} \mathrm{C}$ & $65-250^{\circ} \mathrm{C}$ & $15 \mathrm{C}-220^{\circ} \mathrm{C}$ & $650^{\circ} \mathrm{C}$ & $1000^{\circ} \mathrm{C}$ & $>1000^{\circ} \mathrm{C}$ \\
\hline Waste heat grade & Low & Low-Medium & Medium & High & Higr & High \\
\hline $\begin{array}{l}\text { Waste heat use } \\
\text { (typical) }\end{array}$ & $\begin{array}{l}\text { Hot water, } \\
\text { abs. cooling }\end{array}$ & $\begin{array}{l}\text { Hot water, } \\
\text { abs cooling }\end{array}$ & $\begin{array}{c}\text { Hot water, } \\
\text { steam, process } \\
\text { heatrabs } \\
\text { cooling }\end{array}$ & $\begin{array}{c}\text { Steam, } \\
\text { process heat, } \\
\text { abscooling }\end{array}$ & $\begin{array}{c}\text { Steam, } \\
\text { process heat, } \\
\text { abs.cooling }\end{array}$ & $\begin{array}{c}\text { Steam, } \\
\text { process heat, abs. } \\
\text { cooling }\end{array}$ \\
\hline $\begin{array}{l}\text { Capital cost } \\
\text { lcurrent est.) (skW) }\end{array}$ & $3000-4000$ & $2500-3000$ & $3000-4000$ & $3000-4000$ & Pre-comm. & $\begin{array}{l}\text { Early commi. } \\
\text { No cost avail. }\end{array}$ \\
\hline $\begin{array}{l}\text { Capital cost } \\
\text { (future goa) (\$\$kW) }\end{array}$ & $400-600$ & $250-500$ & $100 \mathrm{-}-1500$ & $<1000$ & $250-500$ & 500 \\
\hline $\begin{array}{l}\text { Hydrogen } \\
\text { cc-production source }\end{array}$ & $\begin{array}{l}\text { Split reformerII } \\
\text { Electrolyzer I } \\
\text { Pipeline syster }\end{array}$ & \begin{tabular}{|l} 
Split reformer II \\
Electrolyzer I \\
Pipeline syster
\end{tabular} & \begin{tabular}{|l} 
Split reformer I \\
Electrolyzer \\
Pipeline syster
\end{tabular} & Anode tail gas & Anode tail gas & $\begin{array}{l}\text { Split reformer II } \\
\text { Electrolyzer I } \\
\text { Pipeline systerr }\end{array}$ \\
\hline
\end{tabular}




\section{Absorption cooling systems}

Absorption cooling systems are based on the evaporation and condensation of a concentrated solution for producing cold. They can use any type of waste heat, steam, hot liquid or hot gas, providing cold for air conditioning or for low temperature processes. If the waste heat is a gas, a gas to water heat exchanger is needed within an intermediate circuit. These systems are very well adapted for the recovery of waste heat, as it is possible to achieve high rates of efficiency with residual flows of relatively low temperature.

The coolant and the absorbent constitute what is called a working pair. Essentially, the pairs used are: ammonia together with water as absorbent and water together with a water solution of lithium bromide as absorbent.

These systems can be activated by residual flows with temperatures of $60{ }^{\circ} \mathrm{C}$ to $80{ }^{\circ} \mathrm{C}$ and low pressure steam, or residual flows up to $150{ }^{\circ} \mathrm{C}$ if a double effect system is considered. In the case of gaseous flow, we need minimum temperatures of the order of $250{ }^{\circ} \mathrm{C}$, due to the need for intermediate circuit of hot water, designed to generate hot water at a temperature up to $120^{\circ} \mathrm{C}$.

Water/ammonia systems are used for the production of cold at low temperatures (up to $-60^{\circ} \mathrm{C}$ ), and require a heat source from $100{ }^{\circ} \mathrm{C}$ to $120{ }^{\circ} \mathrm{C}$ for simple effect absorption systems. Systems based on water/lithium bromide are used for air conditioning or for cooling processes, in which the temperature is between $5^{\circ} \mathrm{C}$ and $10^{\circ} \mathrm{C}$.

Figure 3 shows the block diagram corresponding to an absorption cooling system of simple effect [6].

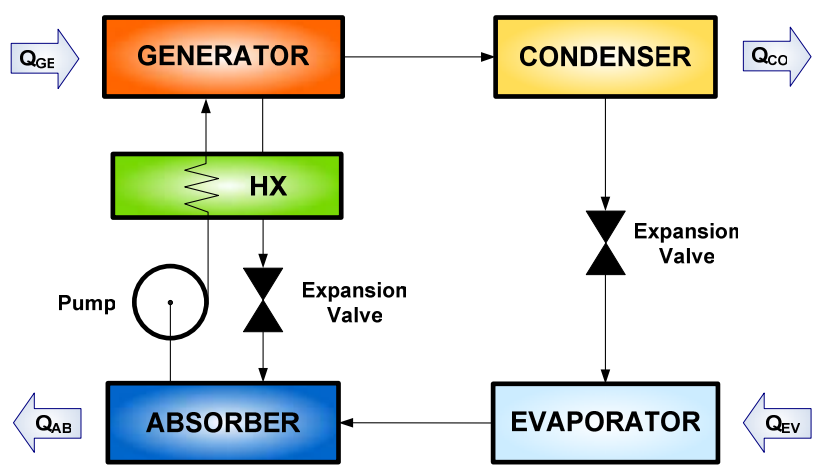

Fig 3. Single effect absorption cooling system

Next, the operation of the absorption cycle shown in figure 3 is explained. The coolant vapour at low pressure and temperature coming from the evaporator is absorbed exothermically in the absorber, by means of a dilution composed by the coolant and one or more substances that act as absorbent. The dilution formed, rich in coolant, is pumped to the generator which works to the same pressure that the condenser. There, applying thermal energy, the vapour previously absorbed is recovered. The remaining dilution, poor in coolant, closes the cycle returning to the absorber, while the coolant returns through the condenser and the evaporator.
Thermal Efficiency is measured in terms of cooling output over heat input. This relation is named Coefficient of Performance, COP. The coefficient of performance is usually used for the evaluation of the heat pumps, including the absorption cycles. The COP of an absorption system in its cooling/heating modes can be obtained by means of equations (1) and (2), respectively.

$$
\begin{gathered}
C O P_{C}=\frac{Q_{E V}}{Q_{G E}} \\
C O P_{H}=\frac{Q_{A B}+Q_{C O}}{Q_{G E}}
\end{gathered}
$$

Moreover, the temperature to which the vapour should be given to feed the absorption unit depends on the coolant available and the cooling temperature to achieve. Figure 4 shows the COP of a process with $\mathrm{NH}_{3}$, of simple effect absorption, depending on the evaporation temperature and the temperature ranges of the coolant water indicated by the colour bands [7].

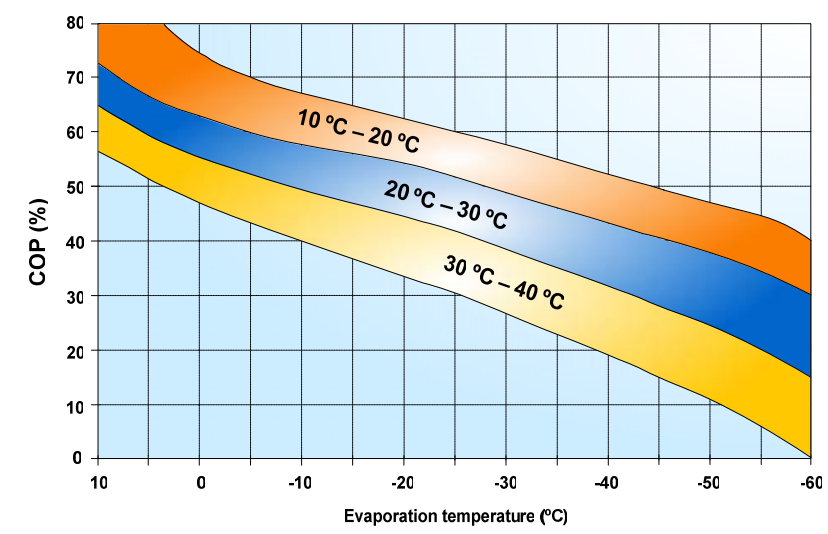

Fig.4. $\mathrm{COP}$ in a $\mathrm{NH}_{3}$ absorption cooling system

Table 3 highlights a summary of the most important properties of absorption cooling systems.

TABLE 3. -Absorption cooler's characteristics

\begin{tabular}{|l|c|c|c|}
\hline \multicolumn{1}{|c|}{ INDICES } & $\begin{array}{c}\mathrm{NH}_{3} \\
\text { ABSORPTION }\end{array}$ & \multicolumn{2}{c|}{$\begin{array}{c}\text { LiBr } \\
\text { ABSORPTION }\end{array}$} \\
\hline EFFECT & SINGLE & SINGLE & DOUBLE \\
\hline COOLING CAPACITY $(\mathrm{kW})$ & $20-2500$ & $300-5000$ & $300-5000$ \\
\hline THERMAL COP & $0,6-0,7$ & $0,5-0,6$ & $0,9-1,1$ \\
\hline TEMPERATURE RANGE $\left({ }^{\circ} \mathrm{C}\right)$ & $120-132$ & $120-132$ & $150-170$ \\
\hline MACHINE COSTS (EIton) & 1250 to 1750 & 870 to 920 \\
\hline
\end{tabular}

In this context, it can be emphasized the use of the waste heat from the fuel cell to activate heating, hot water and cooling systems. This technology is included in the cogeneration techniques driven by the Council Directive 2004/8/EC, February 11th 2004, of the European Parliament.

The efficiency of the cogeneration plants measured through the EEE (Equivalent Electrical Efficiency), for 
cold production (trigeneration), is evaluated in different ways in different countries. These differences are due to different criteria when considering the transformation of cold into primary energy. The efficiency can be obtained from expression (3).

$$
E E E=\frac{E}{Q-\frac{V}{0.9}}
$$

Where, EEE is the Equivalent Electrical Efficiency, $E$ is the electricity prodcued, $Q$ is the consumption of primary energy measured by the fuel's LHV and $V$ is the heat energy obtained from cogeneration and used to meet the thermal demand.

The simplest form of assessment is to consider that the cold is obtained in an absorption machine which uses the heat produced in a cogeneration plant. In this sense, the Directive indicates that the heat is useful when it is economically justifiable (it has a fair price) and, in case of not being produced with this plant, an alternative system should be used. This system would be fundamentally the compression chiller, in the case of cold production.

If the heat is useful, for the purpose of the European Directive, the trigeneration plant can be evaluated as a cogeneration plant, considering all the heat used in producing cold. The evaluation will be carried out using Annexes II and III of the European Directive. The heat used in the generation of cold can be considered useful if the following conditions are met [8]:

- In the generation of cold for air conditioning $\left(5 \div 7^{\circ} \mathrm{C}\right)$ is useful:

- All the heat used in simple effect machines, whenever this heat has a temperature lower than $120^{\circ} \mathrm{C}$.

- $\quad$ All the heat used in double effect machines, whenever their temperature is lower than $180^{\circ} \mathrm{C}$.

- In the generation of industrial cold, for cooling levels up to $-50{ }^{\circ} \mathrm{C}$, is useful all the heat consumed in absorption machines, whenever the temperature is lower than $180^{\circ} \mathrm{C}$.

\section{Trigeneration systems with fuel cells}

The development of fuel cell technologies is creating great opportunities for research in the area of the power generation. As an example, figure 5 shows the different subsystems that integrate a PEM fuel cell system. In this system, the residual heat allows to have hot water with temperatures that usually oscillate in the range of $80{ }^{\circ} \mathrm{C}$. This temperature is enough to trigger absorption cooling cycles.

This section presents some of the systems proposed for trigeneration using fuel cells. The idea is to obtain high levels of overall efficiency in terms of energy. These proposals are still in research stage.

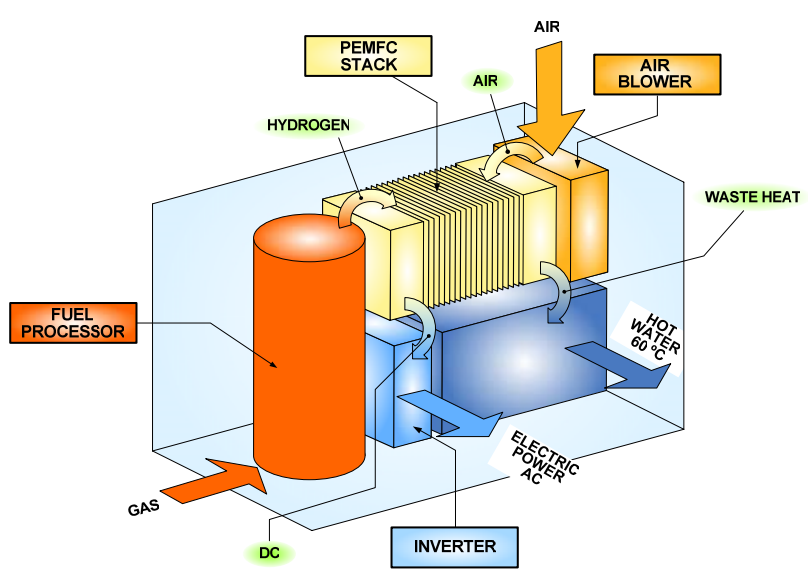

Fig.5. PEMFC system

\section{A. Trigeneration with PEMFC}

Around $25 \%$ of primary energy consumption in some countries is intended for heating places and hot water supply. As the temperature levels necessary to meet these demands are relatively low, PEMFC technology becomes the most appropriate.

Figure 6 shows the PEMFC technology working in trigeneration mode [9].

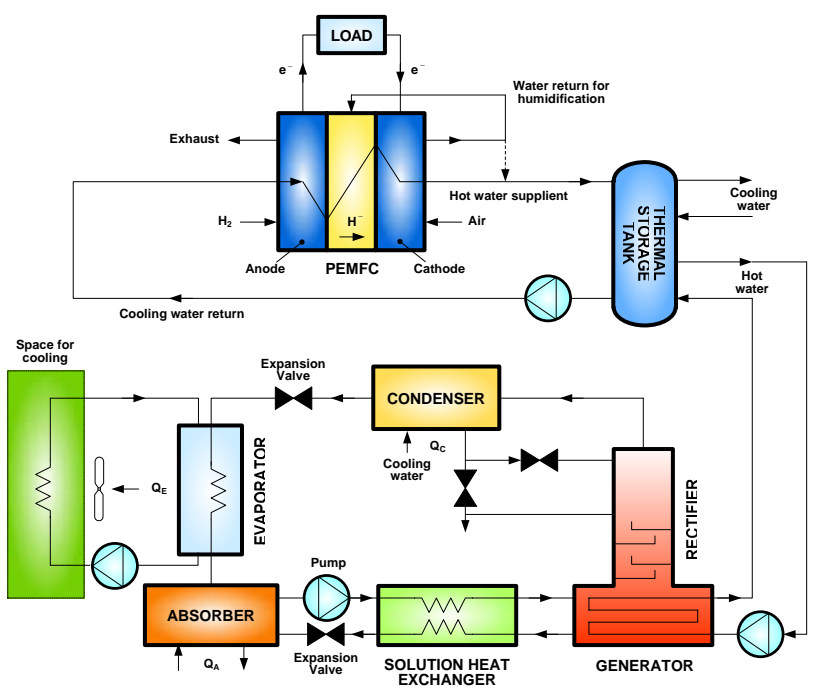

Fig.6. Diagram of a PEMFC trigeneration system

Simulation software has been developed to determine the optimum operation of the air conditioning system during the process of trigeneration. A PEMFC of $1 \mathrm{~kW}$ has been considered, with an electric efficiency of $40 \%$ and a thermal efficiency of $30 \%$, working at full load. The results obtained have shown that it is feasible to use this technology in poligeneration processes, showing that the generation system operates in a very appropriate way with temperatures of the generator between 60 and $65{ }^{\circ} \mathrm{C}$. This temperature is compatible with the temperature of the heat liberated by the PEMFC, which usually is located in the range of $80{ }^{\circ} \mathrm{C}$. The COP varies between 0,44 and 0,57 , for evaporation temperatures of 5 to $10^{\circ} \mathrm{C}$, respectively. 


\section{B. Trigeneration with PAFC}

This subsection presents the use of PAFC technology to operate the air conditioning in a facility located in Kuwait [10]. In this country, air conditioning machines consume more than $75 \%$ of the electricity generated at peak load time.

Figure 7 shows the configuration adopted by the absorption cooling system, using PAFC technology. This system has a capacity of $200 \mathrm{~kW}$ of rated power and produces $105 \mathrm{~kW}$ of thermal power at $120{ }^{\circ} \mathrm{C}$ and 100 $\mathrm{kW}$ at $60{ }^{\circ} \mathrm{C}$. The system uses water/lithium bromide as working pair, and has an electrical efficiency of $45 \%$ at full load and a thermal efficiency of 35\%.

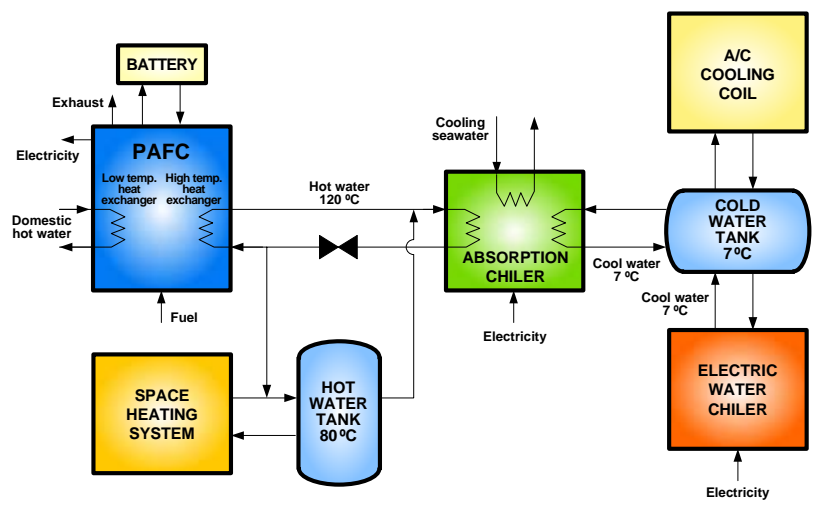

Fig.7. Air conditioning system with PAFC

\section{Trigeneration with $\mathrm{MCFC}$}

Figure 8 shows the technology MCFC integrated in a cooling system by absorption [11].



Fig.8. Cooling system with MCFC

This cooling system with a MC fuel cell has shown results of electric efficiency of $42,27 \%$ and thermal efficiency of $44,21 \%$. Therefore, a global efficiency in the use of the fuel of $86,48 \%$ can be obtained.
Trigeneration with SOFC

This subsection presents the SOFC technology used to obtain air conditioning or hot water in buildings. The system uses water/lithium bromide as working pair, in an absorption cooling cycle. The results show that this combination of technologies presents major technical and environmental advantages [12].

Figure 9 shows the configuration adopted with the SOFC technology, considering both, electric and thermal power generation.

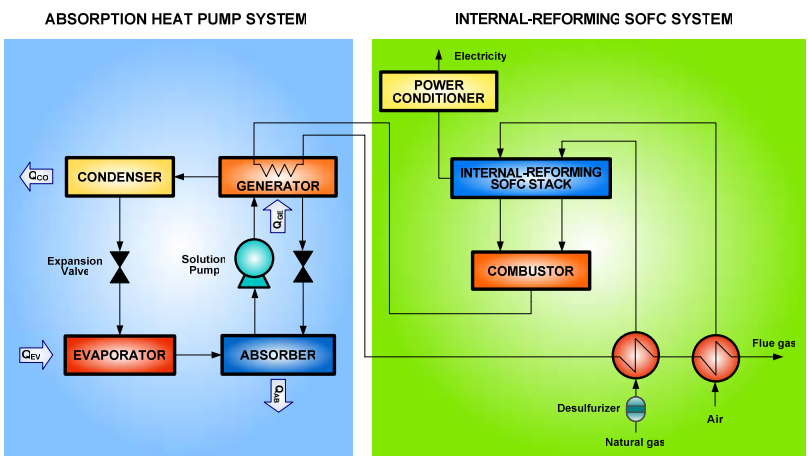

Fig.9. Schematic diagram of the basic configuration of a combined system

The SOFC proposed in this example is a pre-commercial tubular model of $110 \mathrm{~kW}$, developed by SiemensWestinghouse. The results obtained have been a $\mathrm{COP}_{\mathrm{C}}$ of 1,01 and a $\mathrm{COP}_{\mathrm{H}}$ of 0,84 (see equations (1) and (2)). Besides, the electric efficiency of the system is $43,3 \%$, the thermal efficiency in heating is $43,7 \%$, the thermal efficiency in cooling is 52,6\% and the thermal efficiency in hot water production is $46,7 \%$. This performance provides results of global efficiency in the three operation modes, up to $87,95 \%, 95,9 \%$ and $90 \%$, respectively.

\section{Conclusions}

This paper has presented the most outstanding characteristics in trigeneration processes. This generation modality allows reaching high levels of global efficiency in the use of the fuel, by means of the use of the residual heat coming from the exothermic reaction of fuel cells.

In this context, it is noteworthy that the air conditioning (heating in winter and air conditioning in summer) is a consumer of energy of the first order in many countries. In spite of the high efficiency of the mechanical compression devices for cooling, the required total power and its concentration in certain time ranges outlines important problems of capacity and regulation in the power system. These problems can influence the stability of supply and the price of energy in peak hours. In order to overcome these problems, it is interesting to introduce cooling techniques fed by heat instead of electric power. Especially interesting are the systems able to use heat sources of low temperature (lower than $100{ }^{\circ} \mathrm{C}$ ), that is to say, able to take advantage of the residual heats of industrial origin or produced in cogeneration facilities. 
In relation to the industrial processes that require heat, they are classified by the temperature level of the heat required. Thus, the following classification can be made:

- $\quad$ Processes of low temperature, lower than $100{ }^{\circ} \mathrm{C}$ : heating or cooling places, hot water and agricultural production.

- $\quad$ Processes to half temperature, between 100 - $300{ }^{\circ} \mathrm{C}$ : textile industries, sugar factories and some chemical industries. In these processes the heat is usually given as vapour.

- $\quad$ Processes of high temperature, between $300-700{ }^{\circ} \mathrm{C}$ : some chemical industries.

Thus, taking into account the thermal characteristics of fuel cells, this classification process can be served by one of the different fuel cell technologies (PEMFC, PAFC, MCFC and SOFC).

Finally, from the point of view of the operation of the electrical system, fuel cells can operate in two ways: constant power or load following. In this regard, it should be noted that high temperature fuel cells conform more to the first mode of operation, while low temperature fuel cells are more suitable for the second mode, due to lower start up times.

\section{Acknowledgements}

The work presented in this paper has been carried out by the research team of Project ENE2006-15700-CO202/CON, supported by the Ministry of Education and Science of Spain and by the Regional Council of Guipuzcoa.

\section{References}

[1] I. Zamora, J.I. San Martín, A.J. Mazón, J.J. San Martín, V. Aperribay, J.M ${ }^{\mathrm{a}}$ Arrieta, "Cogeneration in Electrical Microgrids”, International Conference on Renewable Energy and Power Quality, Spain, 2006.

[2] The National Renewable Energy Laboratory, NREL. The Department of Energy, DOE, 2003.

[3] "Fuel Cell Handbook", U.S. Department of Energy, Nacional Energy Technology Laboratory, B/T books, 2004.

[4] M. H. Nehrir, C. Wang, S. R. Shaw, "Fuel Cells: Promising Devices for Distributed Generation", IEEE Power and Energy Magazine, 2005.

[5] U.S. Department of Energy, "Energy Efficiency and Renewable Energy, Hydrogen, Fuels \& Infrastructure Technologies Program.

[6] P. Srikhirin, S. Aphornratana, S. Chungpaibulpatana, "A Review of Absorption Refrigeration Technologies", Renew Sustain Energy, 2001.

[7] EUROPEAN COMMISSION, SAVE Project No.4.1031/Z/01-130/2001.

[8] J. M. Roqueta, M. Márquez "Trigeneration: The heat useful in the production of cold”, 2004.

[9] I. Pilatowsky, R. J. Romero, C. A. Isaza, S. A. Gamboa, W. Rivera, P. J. Sebastian, J. Moreira, "Simulation of an Air Conditioning Absorption Refrigeration System in a Cogeneration Process Combining a Proton Exchange Membrane Fuel Cell”, International Journal of Hydrogen Energy, 2007.

[10] M. A. Darwish, "Building air conditioning system using fuel cell: Case study for Kuwait”, Applied Thermal Engineering, 2007.

[11] J. L. Silveira, E. M. Leal, L. F. Ragonha, "Analysis of a Molten Carbonate Fuel Cell: Cogeneration to produce electricity and cold water", Energy.

[12] F. Zink, Y. Lu, L. Schaefer, "A Solid Oxide Fuel Cell System for Buildings”, Energy Conversion \& Management, 2007. 